

\section{PEPPER DISEASES IN BALKAN REGION}

\section{Rossitza Rodeva', Dimitrina Kostova ${ }^{2}$, Petar Chavdarov ${ }^{3}$, Ioannis Manoussopoulos ${ }^{4}$, Jordan Merkuri ${ }^{5}$, Magdalena Cara ${ }^{5}$, Ilija Karov ${ }^{6}$, Sasa Mitrev 6 , Biljana Kovacevik ${ }^{6}$, Gancho Pasev ${ }^{2}$, Mirjana Mijatovic ${ }^{7}$}

'Institute of Plant Physiology and Genetics, Sofia, Bulgaria; ${ }^{2}$ Maritsa Vegetable Crop Research Institute, Plovdiv, Bulgaria; ${ }^{3}$ Institute for Plant Genetic Resources, Sadovo, Bulgaria; ${ }^{4}$ Plant Protection Institute of Patras - NAGREF, Greece; ${ }^{5}$ University of Tirana, Albania; ${ }^{6}$ Goce Delcev University-Stip, FYR Macedonia; ${ }^{7}$ Institute for Vegetable Crops,

Smederevska Palanka, Serbia;

One of the most important problems affecting pepper production in the Balkan peninsula is the occurrence of common pathogens causing severe diseases and epidemics resulting in reduced and compromised yield. Phytophthora capsici, Botrytis cinerea, Sclerotinia sclerotiorum, Verticillium dahliae, Fusarium spp., Pseudomonas syringae pv. syringae, Xanthomonas vesicatoria, Tobacco mosaic virus (TMV), Cucumber mosaic virus (CMV), Tomato spotted wilt virus (TSWV), Alfalfa mosaic virus, Potato virus Y etc. are among the most devastating and widely distributed pathogens. This region is also characterized with endemic, emerging or newly introduced pathogens threatening pepper production. In the last years new pepper fungal pathogens (Phomopsis capsici and several Colletotrichum spp.) were found in Bulgaria with increasingly frequency. In 2010 a SEE-ERA.NET project started combining the research efforts of 7 scientific institutions from 5 Balkan countries (Albania, Bulgaria, FYR Macedonia, Greece and Serbia). The strategic objectives of the project are: i) to explore Balkan biodiversity of Capsicum spp. in order to extract biotic stress resistant germplasm; ii) to update knowledge about the most economically important and emerging pathogens on Capsicum in the Balkan region and to form pathogen collection; iii) to develop database, concerning the pepper pathogen occurrence in the mentioned regions; iv) to identify areas at differing pathogen risk in the involved Balkan countries and to define risks related to introduction of new pathogen biotypes by trading. Adequate knowledge for pathogens is essential to the management of the caused by them diseases and for solving problems in sustainable and conventional agriculture. First joint collecting expeditions have been carried out. Pathogens have been isolated, identified and characterized mainly as species. Collections have been created and properly preserved in related institutes for further investigations concerning the race and strain specificity of the saved pathogens and host-pathogen interaction.

Keywords: Balkan pathogen biodiversity, disease surveys, virus pathogens. 